\title{
Determinants of Debt Policy and Company's Performance
}

Submitted 08/01/20, 1st revision 30/01/20, 2nd revision 10/02/20, accepted 03/04/20

\author{
Nardi Sunardi ${ }^{1}$, T. Husain ${ }^{2}$, A. Kadim ${ }^{3}$
}

\begin{abstract}
:
Purpose: This research proposes to verify the determinant of debt policy, and company's performance consisting of business risk, asset growth, firm's size, and liquidity.

Approach/Methodology/Design: The research has used quantitative analysis. Seven companies incorporated in retail trade listed on the Indonesian Stock Exchange from 20102019 fulfilled the requirements for sampling. Regression analysis was performed based on panel data analysis.

Findings: The research shows that business risk and firm's size have a positive and significant effect on debt policy, whereas asset growth and liquidity have a positive and not significant effect on debt policy. Furthermore, overall determinant factors have a significant effect on company's performance, except liquidity, which has a significant negative effect. However, the determinant of debt policy and company performance have a significant influence on business risk, asset growth, firm's size, and liquidity.

Practical Implications: The research will contribute to third parties and investors, especially providing funding sources to companies and investment decisions according to debt policy and company's performance.

Originality/Value: The study believes to contribute positively to apprehend the importance of debt policy and the company's performance and add insight into financial studies, especially in the context of Indonesia.
\end{abstract}

Keywords: Company's performance, debt policy, retail trade companies in Indonesia.

JEL classification: C33, G29, G32, N75.

Paper Type: Research article.

ISSN: 2241-4754, H index 10, Q3.

\footnotetext{
${ }^{1}$ Post Graduate Program, Pamulang, University, Banten, Indonesia, e-mail: dosen01030@unpam.ac.id;

${ }^{2}$ Faculty of Economics and Business, Persada Indonesia Y.A.I, University, Jakarta, Indonesia, e-mail: thusain050686@gmail.com

${ }^{3}$ Faculty of Economics and Business, Persada Indonesia Y.A.I, University, Jakarta, Indonesia, e-mail: sakkadim@yahoo.co.id
} 


\section{Introduction}

The rapid growth of the economy will determine an increasingly tight business competition. Companies must maintain the existence of their business to stay alive, let alone the condition of the Indonesian economy which is now increasingly uncertain. On the other hand, investors must be careful in investment to attract investment of capital; the company must also pay attention to its business's progress and growth, thus promising future profits (Gitman and Zutter, 2015).

The purpose of establishing a company is to maintain the continuity of its business, earn profits, and expand its business; it will lead to the goal of improving the welfare of its shareholders. In general, each company has the purpose to increase the company's performance, and the firm's soundness (Kadim and Sunardi, 2019). The company's value is significant as a guideline for shareholders and investors' benefits to make decisions (Husain, Sarwani, Sunardi, and Lisdawati, 2020).

Achieving company goals can be influenced by various factors. One important factor that affects the achievement of corporate objectives is in terms of sources of financing. The company has two external financing sources, namely, through the issuance of long-term debt and issuance of shares. The more long-term debt that originates from foreign debt, the higher the level of trust that will have an impact on Gross Domestic Product and Y / Capita in a country (Hady, 2020). The combination of long-term debt and equity as a provenance of financing is called the capital structure.

Performance is a function of an organization's ability to acquire and manage resources in several different ways to develop a competitive advantage. The financial ratios can show the relationship between the elements that make up the financial statements. Financial ratios are tools used to compare figures derived from comparing one financial statement post with other components with a relevant and significant relationship (Brigham and Houston, 2016).

\section{Literature Review}

\subsection{Company's Performance}

A company's performance is the company's ability to generate profits. Profit allocation asset cost over benefit periods yields an accrual income number that is a more stable and meaningful measure of company performance (Subramanyam, 2014). Profit is often a measure of company performance if observed from the investor's side, they will furnish an appraise based on market prices to a company (Kadim, Sunardi, and Husain, 2020). High profitability makes the company able to fund its operations with funds from internal funds company then, it does not require funds from debt. The bigger a company, the tendency to use external funds is also greater. This is because large companies have large financing needs with alternatives to external funds. 


\subsection{Debt Policy}

Debt policy is the ratio used to regulate how a company's activities are financed with debt. Meanwhile, the debt policy ratio is the ratio used to measure how much the company financed with debt (Fahmi, 2015). Excessive debt usage will endanger the company because the company will enter the extreme leverage category (extreme debt) i.e., companies stuck in high debt levels and difficult to release the debt burden. Therefore, companies should balance how much debt is worth taking and how sources can be used to repay debt.

\subsection{Business Risk}

Business risk is a risk arising from the uncertainty of the company in generating revenue in the future. The company must meet all the obligations arising from the loan obtained by the company. Business risk in a company can be affected by the stability of revenue and operational cost structure (Berk and DeMarzo, 2019). The increase of company business risk had dominated collectively against the company value (Hakim and Sunardi, 2017).

\subsection{Asset Growth}

Growth is an indicator of an advanced company or an enterprise (Brigham and Houston, 2016). The decrease in the company's gross profit margin tends to change both the selling prices and the cost of goods, impacting the company's profits.

\subsection{Firm Size}

Firm size is an asset that is a resource of business equity. The business uses its assets in executing such activities as production and sales. The firm size is classified by current assets and non-current assets (Weygandt, Kimmel, and Kieso, 2018). The size of a company is one factor that companies use to determine the capital structure policy. If the company gets bigger, the bigger fund will be issued, either from debt policy or own capital, to maintain or develop the company.

\subsection{Liquidity}

Liquidity is one of the ratios used to measure strength in paying off its obligations that are due in the short term. Short-term debt occupies a substantial role in cost-of debt, capital structure, and profitability (Abeywardhana and Krishanthi, 2012). If a company uses many current assets, it means the company can generate cash flow to finance its operating and investment activities. Increased current assets show that the company successfully repay its short-term debt, resulting in short-term debt reduced and a decrease in the capital structure proportion.

\subsection{Research Model}


A model is usually used by practitioners to describe a tangible problem by building in a decision making (Sharda, Delen, and Turban, 2013). Furthermore, modeling is everything that is constructed through the boundary and specific parameters that are measured based on structure, form, content, number, and meaning (Husain, 2019). The research model is formulated as follows:

Figure 1. Research Model

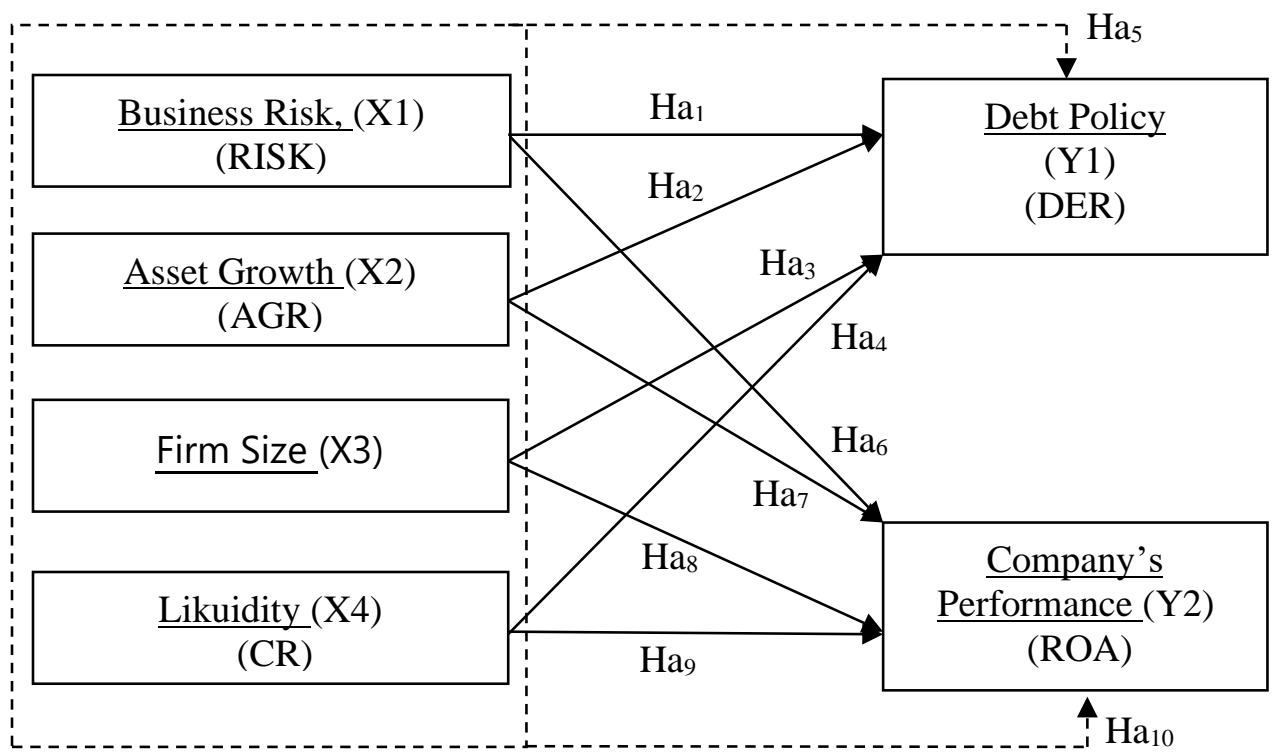

Research Hypotheses:

Hypothesis $\left(\mathrm{Ha}_{1}\right) \quad$ : The influence of Business Risk on Debt Policy

Hypothesis $\left(\mathrm{Ha}_{2}\right)$ : The influence of Asset Growth on Debt Policy

Hypothesis $\left(\mathrm{Ha}_{3}\right) \quad$ : The influence of Firm Size on Debt Policy

Hypothesis $\left(\mathrm{Ha}_{4}\right) \quad$ : The influence of Liquidity on Debt Policy

Hypothesis ( $\left.\mathrm{Ha}_{5}\right) \quad$ : The influence of RISK, AGR, SIZE, and CR on Debt Policy

Hypothesis $\left(\mathrm{Ha}_{6}\right) \quad$ : The influence of Business Risk on Company's Performance

Hypothesis $\left(\mathrm{Ha}_{7}\right) \quad$ : The influence of Asset Growth on Company's Performance

Hypothesis $\left(\mathrm{Ha}_{8}\right)$ : The influence of Firm Size on Company's Performance

Hypothesis $\left(\mathrm{Ha}_{9}\right) \quad$ : The influence of Liquidity on Company's Performance

Hypothesis $\left(\mathrm{Ha}_{10}\right)$ : The influence of RISK, AGR, SIZE, and CR on Company's Performance

\section{Methodology}

This research uses a quantitative approach with each variable or between variables based on the quantitative measurement scale. Data collection techniques used are documentation techniques. Researchers collect quantitative data obtained through non-participant observation or obtained indirectly, by collecting, recording, and reviewing secondary data in corporate financial statements incorporated in retail trade companies in Indonesia in 2010-2019. 
Table 1. Number of Sample Based on Sampling Criteria

\begin{tabular}{|l|l|}
\hline Sample Characteristic & Sample Size \\
\hline $\begin{array}{l}\text { 1) The number of population is a company engaged in the Retail Trade } \\
\text { Company's index listing in IDX period of 2010-2019 }\end{array}$ & 21 \\
\hline $\begin{array}{l}\text { 2) The company does not publish its financial statements and full during } \\
\text { the period of observation }\end{array}$ & $(14)$ \\
\hline Final Sample & $\mathbf{7}$ \\
\hline Observation Year & 10 \\
\hline Observation Amount & $\mathbf{7 0}$ \\
\hline
\end{tabular}

Source: Own calculations.

Table 2. Research Sample

\begin{tabular}{|c|c|c|}
\hline No. & Ticker Code & Retailing Company in Indonesia \\
\hline 1 & CSAP & PT Catur Sentosa Adiprana Tbk. \\
\hline 2 & HERO & PT Hero Supermarket Tbk. \\
\hline 3 & LPPF & PT Matahari Departemen Store Tbk. \\
\hline 4 & ACES & PT Ace Hardware Indonesia Tbk. \\
\hline 5 & AMRT & PT Sumber Alfaria Trijaya Tbk. \\
\hline 6 & MAPI & PT Mitra Adiperkasa Tbk. \\
\hline 7 & RALS & PT Ramayana Lestari Sentosa Tbk. \\
\hline
\end{tabular}

Source: Own calculations.

Table 3. Operationalization of Variables

\begin{tabular}{|l|c|c|c|}
\hline Variable & Proxy & Measurement & Scale \\
\hline $\begin{array}{l}\text { Company's } \\
\text { Performance (Y2) }\end{array}$ & ROA & ROA $=\frac{\text { Total Revenue }}{\text { Total Asset }}$ & Ratio \\
\hline Debt policy (Y1) & DER & DER $=\frac{\text { Total Liability }}{\text { Total Equity }}$ & Ratio \\
\hline Business Risk (X1) & RISK & STD.DEV $=\frac{\text { Net Income }}{\text { Total Equity }}$ & Ratio \\
\hline Asset Growth (X2) & AGR & AGR $=\frac{\text { TA t }- \text { TA t }-1}{\text { TA t }-1}$ & Ratio \\
\hline Firm's Size (X3) & SIZE & Firm's Size $=$ Ln_Total Asset & Ratio \\
\hline Liquidity (X4) & CR & CR $=\frac{\text { Current Assets }}{\text { Current Liabilities }}$ & Ratio \\
\hline
\end{tabular}

Source: Own calculations.

In this research the regression analysis method of panel data was used. To determine one of the three-panel regression approaches there were used the following tests, namely: the Ordinary Least Square (OLS), the Common Effect Model, Fixed Effect Model, Random Effect Model, with the use of Chow test and Hausman test. The data processing activities with EVIEWS version 10.0 is used to assist in analyzing the data used in performing the test of significance of panel data regression analysis.

\section{Results and Discussion}




\subsection{Descriptive}

A description of statistics the factors that determine the debt policy and company's performance of retail trade companies in Indonesia at the period of 2008-2019. Each variable is shown in Table 4:

Table 4. Descriptive Statistics

\begin{tabular}{lcccccc}
\hline & ROA & DER & RISK & \multicolumn{1}{c}{ AGR } & \multicolumn{1}{c}{ SIZE } & CR \\
\hline Mean & 9.710319 & 1.628714 & 18.18213 & 15.91993 & 18.26800 & 210.1636 \\
Median & 6.240700 & 1.655000 & 9.224500 & 13.93895 & 15.76150 & 119.6850 \\
Maximum & 45.78850 & 18.19000 & 565.0476 & 103.3867 & 26.89300 & 1060.000 \\
Minimum & -6.240400 & -4.760000 & -104.0843 & -99.99740 & 13.25700 & 38.88000 \\
Std. Dev. & 11.24512 & 2.524211 & 69.95621 & 22.68413 & 4.539386 & 204.7502 \\
Skewness & 1.648734 & 3.822429 & 6.935001 & -0.976514 & 0.541664 & 2.153800 \\
Kurtosis & 5.240532 & 28.14510 & 55.10718 & 13.81866 & 1.817510 & 7.294452 \\
Jarque-Bera & 46.35540 & 2014.599 & 8480.311 & 352.5018 & 7.501316 & 107.9101 \\
Probability & 0.000000 & 0.000000 & 0.000000 & 0.000000 & 0.023502 & 0.000000 \\
Sum & 679.7223 & 114.0100 & 1272.749 & 1114.395 & 1278.760 & 14711.45 \\
Sum Sq. Dev. & 8725.240 & 439.6432 & 337677.1 & 35505.33 & 1421.815 & 2892661. \\
\hline Observations & 70 & 70 & 70 & 70 & 70 & 70 \\
Cross sections & 7 & 7 & 7 & 7 & 7 & 7 \\
\hline
\end{tabular}

Source: Own calculations.

\subsection{Determinant of Debt Policy}

Based on testing of paired data regression model against the third panel, the conclusions are as follows:

Table 5. Panel Data Regression Model Results

\begin{tabular}{clll}
\hline No & Methods & Testing & Result \\
\hline 1. & Chow-Test & common effect $\leftrightarrow$ fixed effect & fixed effect \\
2. & Langrage Multiplier-Test & common effect $\leftrightarrow$ random effect & random effect \\
3. & Hausman Test & fixed effect $\leftrightarrow$ random effect & fixed effect \\
\hline
\end{tabular}

Source: Own calculations.

Estimation of Partial Panel Data Regression Model (T-Test) and Simultaneous (Test-F) Fixed Effects Model with White-Test Dependent Variable: DER, Method: Pooled EGLS (Crosssection weights) as follows:

Table 6. Pooled EGLS Methods

\begin{tabular}{crrrr}
\hline \hline Variable & Coefficient & Std. Error & t-Statistic & Prob. \\
\hline \hline C & -4.169665 & 1.465861 & -2.844517 & 0.0061 \\
RISK? & 0.030874 & 0.003122 & 9.888297 & 0.0000 \\
AGR? & 0.000203 & 0.003173 & 0.063923 & 0.9492 \\
SIZE? & 0.280724 & 0.076103 & 3.688736 & 0.0005 \\
CR? & 0.000502 & 0.000666 & 0.754180 & 0.4537
\end{tabular}

Fixed Effects (Cross)

_ACES--C $\quad-3.781187$




$\begin{array}{lr}\text { _AMRT--C } & 2.168510 \\ \text { _CSAP--C } & 0.516591 \\ \text { _HERO--C } & 0.966483 \\ \text { _LPPF--C } & 0.141097 \\ \text { _MAPI--C } & -0.274218 \\ \text { _RALS--C } & 0.262724\end{array}$

\begin{tabular}{|c|c|c|}
\hline \multicolumn{3}{|c|}{ Effects Specification } \\
\hline \multicolumn{3}{|c|}{ Cross-section fixed (dummy variables) } \\
\hline \multicolumn{3}{|c|}{ Weighted Statistics } \\
\hline R-squared & 0.927783 Mean dependent var & 2.809593 \\
\hline Adjusted R-squared & 0.915543 S.D. dependent var & 2.039438 \\
\hline S.E. of regression & 0.778501 Sum squared resid & 35.75773 \\
\hline F-statistic & $75.79850 \quad$ Durbin-Watson stat & 1.537353 \\
\hline Prob(F-statistic) & 0.000000 & \\
\hline \multicolumn{3}{|c|}{ Unweighted Statistics } \\
\hline R-squared & $\begin{array}{cc}0.845073 & \text { Mean dependent var }\end{array}$ & 1.628714 \\
\hline Sum squared resid & 68.11282 Durbin-Watson stat & 1.705562 \\
\hline
\end{tabular}

Source: Own calculations.

Estimation Regression Data Panel Result for Fixed Effect as follows:

Table 6. Fixed Effect Estimation

\begin{tabular}{ccccc}
\hline Model & Adjusted $\boldsymbol{R}^{\mathbf{2}}$ & Prob. $(\boldsymbol{F}$-stat. $) \boldsymbol{\alpha}-\mathbf{0 , 0 5}$ & \multicolumn{2}{c}{ Probability $\boldsymbol{\alpha}-\mathbf{0 , 0 5}$} \\
\hline \multirow{3}{*}{ Fixed Effect } & 0.915543 & & RISK & Significant \\
& & 0.0000 & AGR & Not Significant \\
& & & SIZE & Significant \\
& & & CR & Not Significant \\
\hline
\end{tabular}

Source: Own calculations.

\subsection{Determinant of Company Performance's}

Based on testing of paired data regression model against the third panel, the conclusions are as follows:

Table 7. Panel Data Regression Model Results

\begin{tabular}{clll}
\hline No & Methods & Testing & Result \\
\hline 1. & Chow-Test & common effect $\leftrightarrow$ fixed effect & fixed effect \\
2. & Langrage Multiplier-Test & common effect $\leftrightarrow$ random effect & random effect \\
3. & Hausman Test & fixed effect $\leftrightarrow$ random effect & fixed effect \\
\hline
\end{tabular}

Source: Own calculations.

Estimation of Partial Panel Data Regression Model (T-Test) and Simultaneous (Test-F) Fixed Effects Model with White-Test Dependent Variable: ROA, Method: Pooled EGLS (Crosssection weights) as follows:

Table 8. Pooled EGLS Methods

\begin{tabular}{crrrr}
\hline \hline Variable & Coefficient & Std. Error & t-Statistic & Prob. \\
\hline \hline C & 40.49693 & 10.67778 & 3.792635 & 0.0004 \\
RISK? & 0.069421 & 0.025236 & 2.750842 & 0.0079
\end{tabular}




\begin{tabular}{|c|c|c|c|c|}
\hline AGR? & 0.051638 & 0.024305 & 2.124567 & 0.0378 \\
\hline SIZE? & -1.671459 & 0.547373 & -3.053601 & 0.0034 \\
\hline CR? & -0.011118 & 0.010160 & -1.094298 & 0.2783 \\
\hline \multicolumn{5}{|c|}{ Fixed Effects (Cross) } \\
\hline _ACES--C & 27.72057 & & & \\
\hline _AMRT--C & -11.49302 & & & \\
\hline CSAP--C & -2.655413 & & & \\
\hline _HERO--C & -12.65852 & & & \\
\hline LPPF--C & 5.559873 & & & \\
\hline _MAPI--C & -0.608013 & & & \\
\hline RALS--C & -5.865479 & & & \\
\hline \multicolumn{5}{|c|}{ Effects Specification } \\
\hline \multicolumn{5}{|c|}{ Cross-section fixed (dummy variables) } \\
\hline \multicolumn{5}{|l|}{ Weighted Statistics } \\
\hline$\overline{\text { R-squared }}$ & 0.797625 & Mean dependent var & & 1016.70734 \\
\hline Adjusted R-squared & 0.763324 & S.D. dependent var & & 14.07682 \\
\hline S.E. of regression & 6.293667 & Sum squared resid & & 2337.004 \\
\hline F-statistic & 23.25380 & Durbin-Watson stat & & 1.581690 \\
\hline $\operatorname{Prob}$ (F-statistic) & 0.000000 & & & \\
\hline \multicolumn{5}{|c|}{ Unweighted Statistics } \\
\hline R-squared & 0.637424 & Mean dependent var & & 9.710319 \\
\hline Sum squared resid & 3163.567 & Durbin-Watson stat & & 1.799523 \\
\hline
\end{tabular}

Source: Own calculations.

Estimation Regression Data Panel Result for Fixed Effect as follows:

Table 9. Fixed Effect Estimation

\begin{tabular}{ccccc}
\hline Model & Adjusted $\boldsymbol{R}^{2}$ & Prob. $(\boldsymbol{F}$-stat. $)$ & $\boldsymbol{\alpha}-\mathbf{0 , 0 5}$ & \multicolumn{2}{c}{ Probability $\boldsymbol{\alpha}-\mathbf{0 , 0 5}$} \\
\hline \multirow{3}{*}{ Fixed Effect } & 0.763324 & & RISK & Significant \\
& & 0.0000 & AGR & Significant \\
& & & SIZE & Significant \\
& & & CR & Not Significant \\
\hline
\end{tabular}

Source: Own calculations.

\subsection{Discussion}

Table 10. Summarizes of Data Panel Regression Results

\begin{tabular}{lcccccc}
\multirow{2}{*}{$\begin{array}{l}\text { Independent } \\
\text { Variable }\end{array}$} & \multicolumn{3}{c}{$\begin{array}{c}\text { Model 1: } \\
\text { Determinant of Debt policy }\end{array}$} & \multicolumn{2}{c}{$\begin{array}{c}\text { Model 2: Determinant of } \\
\text { Company's Performance }\end{array}$} \\
\cline { 2 - 7 } & Coefficients & “Prob.” & "Sig./Not Sig.” Coefficients & “Prob.” & "Sig./Not Sig.” \\
\hline RISK & 0.030874 & 0.0000 & Significant & 0.069421 & 0.0079 & Significant \\
AGR & 0.000203 & 0.9492 & Not Significant & 0.051638 & 0.0378 & Significant \\
SIZE & 0.280724 & 0.0005 & Significant & -1.671459 & 0.0034 & Significant \\
CR & 0.000502 & 0.4537 & Not Significant & -0.011118 & 0.2783 & Not Significant
\end{tabular}

Source: Own calculations.

Based on the summary of data panel regression results against the third panel, the discussion is as follows: 
1. The business risk partially has a positive and significant effect on debt policy.

2. Asset growth partially has a positive and not significant effect on debt policy.

3. Firm's size partially has a positive and significant effect on debt policy.

4. Liquidity partially has a positive and not significant effect on debt policy.

5. RISK, AGR, SIZE, and CR simultaneously proved to have a positive and significant effect on DER and explained debt policy variables by 92.78 percent. In contrast, the remaining $7.22 \%$ were affected by other variables not covered in this research. The dominant variable or the debt policy variables' highest dominance is the SIZE (0.280724), whereas the lowest dominance variable is AGR (0.000203). Companies that have the highest rate of sensitivity simultaneously to debt policy are AMRT ticker code with a constant value of 2.168510 , and the smallest change of sensitivity to debt policy is ACES ticker code with a constant value of -3.781187 .

6 . The business risk partially has a positive and not significant effect on the company's performance.

7. Asset growth partially has a positive and significant effect on the company's performance.

8. Firm's size partially has a negative and significant effect on the company's performance.

9. Liquidity partially has a negative and not significant effect on the company's performance.

10. RISK, AGR, SIZE, and CR simultaneously have a positive and significant effect on company's performance, and able to explain the company's performance variable by 79.76 percent while the remaining $20.24 \%$ is influenced by other variables that are not tested in this research. The dominant variable or the highest dominance on the company's performance variable is the SIZE of 1.671459, whereas the lowest dominance is the $\mathrm{CR}$ of 0.011118 . Companies that have the highest sensitivity rate simultaneously to the company's performance of the largest companies are ACES ticker code with a constant value of 27.72057 , and the smallest change of sensitivity is the HERO ticker code with a constant value of -12.65852 .

\section{Concluding Remarks}

This study conducts a determinant of debt policy and company performance's consist of business risk, asset growth, firm size, and liquidity on the retail trade company's in the Indonesian Stock Exchange (IDX) for the period 2010-2019 with findings that only business risk and firm size had a significant effect on the debt policy. In contrast, growth assets and liquidity would not significantly affect. Furthermore, liquidity was an insignificant effect on company performance's while business risk, asset growth, and firm size were significantly affected. The two results of the significance test were obtained with a high coefficient of determination, viz. 0.927783 or 92.78 percent for determinants of debt Plpolicy and 0.797625 or 79.76 percent for company's performance.

These findings are stimulating for third parties and investors. First, a party that provides funding sources to companies must be cautious with the company's liquidity 
in earning revenue because is indicated by insignificant results on the debt policy and company's performance with DER and ROA proxies. Second, investors can make investment decisions by considering the ROA proxy.

The future research framework concerning the company's value can use other measurements widely used by researchers, such as the Tobin's Q ratio and Price-toBook Value (PBV) ratio. Besides that, return on equity (ROE) proxies can be added with ROA proxies to improve the findings and results in future studies.

\section{References:}

Abeywardhana, Y., Krishanthi, D. 2012. Financing decision, cost of debt and profitability: evidence from non-financial SMEs in the UK. Birmingham Business School. University of Birmingham.

Berk, J., DeMarzo, P. 2019. Chapter 16: Financial Distress, Managerial Incentives, and Information. Corporate Finance (5th - Global), 181-195. London, Pearson Education.

Brigham, E.F., Houston, J.F. 2016. Fundamentals of Financial Management. Boston, Cengage Learning.

Fahmi, I. 2015. Analisis Laporan Keuangan. Bandung, Alfabeta.

Gitman, L.J., Zutter, C.J. 2015. Principles of Managerial Finance, Boston, Prentice Hall.

Hady, H. 2020. Manajemen Keuangan Internasional. Jakarta, Bogor, Indonesia, Penerbit Mitra Wacana Media.

Hakim, L., Sunardi, N. 2017. Determinant of leverage and it's implication on company value of real estate and property sector listing in IDX period of 2011-2015. Man in India, 97(24), 131-148.

Husain, T. 2019. An Analysis of Modeling Audit Quality Measurement Based on Decision Support Systems (DSS). European Journal of Scientific Exploration, 2(6), 1-9.

Husain, T., Sarwani, Sunardi, N., Lisdawati. 2020. Firm's Value Prediction Based on Profitability Ratios and Dividend Policy. Finance \& Economics Review, 2(2), 13 26.

Kadim, A., Sunardi, N. 2019. E-views Analysis: Determinants Tourism, Restaurant and Hotel Company's Soundness and Performance. The 1st Inter-University Forum the Strengthening Acedemic Competency (IFSAC) 2018, 1(1), 332-340.

Kadim, A., Sunardi, N., Husain, T. 2020. The modeling firm's value based on financial ratios, intellectual capital and dividend policy. Accounting, 6(5), 859-870.

Sharda, R., Delen, D., Turban, E. 2013. Business Intelligence and Analytics: Systems for Decision Support. N.J., Pearson.

Subramanyam, K.R. 2014. Financial Statement Analysis (11th / International). New York, McGraw-Hill.

Sunardi, N., Augusta, E., Kadim, A., Tumanggor, M., Oktrima, B. 2018. The Effects of Bank Soundness with the RBBR Approach (Risk Base Bank Rating) of Cost Efficiency and its Implications on Sharia Bank Performance in Indonesia for the Period of 2012-2016. International Journal of Economic Research, 15(1).

Supranto, J., Limakrisna, N. 2019. Petunjuk Praktis Penelitian Ilmiah untuk Menyusun Skripsi. Tesis dan Disertasi. Bogor, Penerbit Mitra Wacana Media.

Weygandt, J.J., Kimmel, P.D., Kieso, D.E. 2018. Accounting Principles. New Jersey, John Wiley \& Sons, Inc. 